\title{
PENINGKATKAN HASIL BELAJAR MATEMATIKA PESERTA DIDIK KELAS X.IPS MENGGUNAKAN METODE MIND MAPPING DENGAN PENDEKATAN SAINTIFIK DI SMAN 9 YOGYAKARTA
}

\author{
ATI LASMANAWATI \\ SMA Negeri 9 Yogyakarta \\ E-mail: lasmanawatie77@gmail.com
}

\begin{abstract}
ABSTRAK
Karya tulis ini merupakan hasil penelitian dari pengalaman nyata penulis sebagai seorang guru, dalam proses pembelajaran menggunaan metode mind mapping dengan pendekatan saintifik. Metode ini merupakan salah satu alternatif strategi pembelajaran terbaik yang pernah dilakukan sebagai upaya untuk meningkatkan hasil belajar matematika peserta didik yang ada di kelas X.IPS, pada materi Pertidaksamaan Nilai Mutlak, materi Persamaan dan Pertidaksamaan Rasional, materi Persamaan dan Pertidaksamaan Irasional Tahun Ajaran 2019/2020 di SMA Negeri 9 Yogyakarta. Hasil belajar yang akan ditingkatkan mencakup kompetensi sikap, pengetahuan, dan keterampilan, sehingga instrumen yang digunakan selama proses belajar mengajar terdiri dari tes tertulis (tes evaluasi akhir), penugasan, tes praktik/ unjuk kerja, dan proyek, dengan instrumen non tes berupa lembar angket sikap, wawancara tertulis, dan observasi yang dilakukan langsung oleh guru. Keberhasilan proses pembelajaran terlihat sekali dari perolehan nilai rata-rata hasil belajar baik pada kompetensi sikap, pengetahuan dan keterampilan peserta didik yang telah mencapai nilai melampaui KKM (> 73). Besarnya presentase capaian nilai rata-rata hasil belajar yang diperoleh peserta didik kelas X.IPS untuk materi Pertidaksamaan Nilai Mutlak untuk kompetensi sikap rata-rata baik, pengetahuan $79,80 \%$, dan keterampilan $81,01 \%$. Pada materi Persamaan dan Pertidaksamaan Rasional diperoleh capaian untuk kompetensi sikap rata-rata baik, pengetahuan $80,75 \%$, dan keterampilan 82,0\%. Sedangkan pada materi Persamaan dan Pertidaksamaan Irasional diperoleh capaian untuk kompetensi sikap rata-rata baik, pengetahuan $82,05 \%$, dan keterampilan $82,75 \%$. Hasil ini menunjukkan bahwa telah terjadi peningkatan hasil belajar matematika peserta didik setelah menggunakan metode mind mapping dengan pendekatan saintifik.
\end{abstract}

Kata Kunci : Metode Pembelajaran, Mind Mapping, Belajar Matematika

\section{PENDAHULUAN}

Matematika merupakan salah satu mata pelajaran yang mendukung terciptanya tujuan pendidikan nasional, karena melalui matematika peserta didik memiliki kemampuan memperoleh, memilih dan mengelola informasi; kemampuan untuk dapat berpikir secara kritis, sistematis, logis, kreatif; dan kemampuan untuk bekerja sama secara efektif. Oleh karena itu, demi tercapainya kompetensi kelulusan yang diharapkan sesuai dengan tujuan pendidikan nasional, proses pembelajaran pada mata pelajaran matematika harus sesuai dengan karakteristik Kurikulum 2013.

Salah satu pengembangan proses pembelajaran yang sesuai dengan karakteristik Kurikulum 2013 adalah penggunaan pendekatan saintifik yang mendorong peserta didik agar lebih mampu dalam mengembangkan kemampuan mengamati, menanya, mengeksplorasi, mengasosiasi, dan mengomunikasi atau mempresentasikan. Oleh karena itu dalam pelaksanaannya di depan kelas, seorang guru tidak cukup membekali peserta didik dengan berbagai pengetahuan matematika, tetapi lebih dari itu diperlukan adanya upaya nyata yang dilakukan secara intensif untuk menumbuhkembangkan kemampuan memperoleh pengetahuan matematika dengan menemukan sendiri maupun secara berkolaborasi serta kemampuan menerapkannya dalam situasi masyarakat modern.

Pendekatan saintifik yang digunakan dalam proses pembelajaran matematika yang dipadu dengan pelaksanaan penilaian autentik yang mengukur ketercapaian kompetensi lulusan yang 


\section{STRATEGY : Jurnal Inovasi Strategi dan Model Pembelajaran Vol 1. No 1. Juli Tahun 2021 e-ISSN : 2798-5466 P-ISSN : 2798-5725}

menyeimbangkan kemampuan sikap, pengetahuan dan keterampilan peserta didik, sebagai penguatan karakteristik Kurikulum 2013, mendukung empat pilar pembelajaran yang ditetapkan UNESCO untuk dapat dijadikan pedoman dalam pembelajaran matematika melalui kegiatan bersosialisasi dan berkomunikasi dalam matematika (Mulyana : 2008). Hal ini dilakukan melalui bekerja dan belajar bersama dalam kelompok kecil (cooperative learning), menghargai pendapat orang lain, menerima pendapat yang berbeda, belajar mengemukakan pendapat dan atau bersedia sharing idea dengan orang lain dalam kegiatan matematika.

Mata pelajaran matematika yang harus mereka kuasai dengan baik, ternyata menjadi mata pelajaran yang sulit, menakutkan, dan kurang menarik minat peserta didik untuk mempelajarinya, terutama yang dirasakan oleh peserta didik di kelas IPS. Sering kita dengar dari keluhan yang dilontarkan oleh sebagai besar peserta didik saat mempelajari matematika, bahwa matematika merupakan sesuatu yang tidak menyenangkan, membosankan, dan memusingkan. Hal ini berdampak pada rendahnya sikap positif peserta didik selama proses pembelajaran matematika, yang diantaranya ditunjukkan dengan sikap kurang disiplin, kurang bertanggung jawab, tidak ada motivasi dalam belajar, merasa malas atau kurang berusaha untuk dapat menyelesaikan berbagai permasalahan matematika yang mereka hadapi, kurangnya toleransi antar rekan sebaya, dan sikap negatif lain yang dapat menghambat keberhasilan peserta didik dalam belajar matematika.

Rendahnya hasil belajar peserta didik, yang diawali dari rendahnya sikap positif peserta didik terhadap mata pelajaran matematika, ternyata sikap negatif ini berlanjut pada rendahnya penguasaan materi atau aspek pengetahuan peserta didik, yang berdampak pula pada rendahnya kemampuan keterampilan yang seharusnya dikuasai dengan baik oleh peserta didik. Pernyataan ini didukung oleh hasil penelitian Ekawati (2014), bahwa peserta didik yang tidak lagi memiliki motivasi dan minat dalam belajar matematika, akan bersikap acuh tak acuh terhadap penjelasan guru, tidak mau belajar dan ini akan berdampak pada tidak baiknya hasil belajar yang diperoleh siswa tersebut.

Penggunaan pendekatan saintifik sebagai salah satu bagian dari karakteristik Kurikulum 2013 dan dengan menjadikan empat pilar UNESCO sebagai acuan pendidik dalam melakukan proses pembelajaran matematika, diharapkan dapat meningkatkan hasil belajar matematika dengan ditandai adanya keseimbangan pencapaian kompetensi sikap, pengetahuan dan keterampilan secara optimal. Oleh karena itu dalam proses pembelajaran pada penelitian ini, guru mencoba menggunakan sebuah metode pembelajaran yang dipadukan dengan pendekatan saintifik dalam proses pembelajaran dengan penilaian yang dilakukan secara autentik. Metode yang digunakan yaitu metode mind mapping dengan pendekatan saintifik.

Berdasarkan latar belakang yang telah diuraikan di atas, maka yang menjadi ruang lingkup masalah penelitian ini adalah; "bagaimanakah peningkatan hasil belajar matematika peserta didik kelas X.IPS yang menggunakan metode mind mapping dengan pendekatan saintifik Tahun Pelajaran 2019/2020 di SMA Negeri 9 Yogyakarta?." Sedangkan tujuan dari penelitian ini adalah mengkaji dan mendeskripsikan peningkatan hasil belajar matematika peserta didik kelas X.IPS yang menggunakan metode mind mapping dengan pendekatan saintifik Tahun Pelajaran 2019/2020 di SMA Negeri 9 Yogyakarta. Adapun materi yang dikaji dalam penelitian ini mencakup materi Pertidaksamaan Nilai Mutlak, Persamaan dan Pertidaksamaan Rasional, serta Persamaan dan Pertidaksamaan Rasional.

Manfaat hasil penelitian berdasarkan pengalaman nyata guru yang tertuang dalam karya tulis ini, diantaranya: 1) bagi penulis, selain sebagai upaya mengatasi permasalahan berkaitan dengan rendahnya hasil belajar matematika peserta didik, dan 2) bagi peserta didik, diharapkan dapat menumbuhkan jiwa kemandirian dalam belajar, bertanggung jawab dengan tugas yang dibebankan, lebih aktif dan kreatif, bersikap toleran dalam menghadapi perbedaan, dan belajar matematika sambil mengembangkan kreativitas dalam menggambar (mengolah kesimbangan otak kiri dan kanan).

Metode mind mapping (pemetaan pikiran) merupakan cara mencatat yang efektif, efesien, kreatif, menarik, mudah dan berdaya guna karena dilakukan dengan cara memetakan pikiran- 
pikiran kita (Swadarma : 2013). Hal ini sejalan dengan pendapat Olivia (2008), bahwa mind mapping merupakan gabungan dari creative thingking dan active learning. Karena tanpa peserta didik sadari, sebenarnya mereka sedang "belajar" sambil mencatat dan menggambar sekaligus merangsang kecerdasan majemuk, terutama kecerdasan visual spasial, verbal (lingusitik), logis matematis, kinestatis dan interpersonal. Sedangkan menurut Shoimin (2014) bahwa mind mapping merupakan sebuah teknik pemanfaatan seluruh otak dengan menggunakan citra visual dan prasarana grafis lainnya untuk membentuk kesan.

Menurut Tony Buzan bahwa dengan memanfaatkan gambar dan teks ketika seseorang mencatat atau mengeluarkan suatu ide yang ada di dalam pikiran, kita telah menggunakan dua belahan otak secara sinergis (Olivia : 2013). Sehingga Olivia (2013) mengemukkan beberapa keunggulan dari metode mind mapping, yaitu: 1) sebagai cara mudah menggali informasi dari dalam dan dari luar otak; 2) sebagai cara baru belajar dan berlatih dengan cepat dan ampuh; 3) sebagai cara membuat catatan agar tidak membosankan; 4) sebagai cara terbaik untuk mendapatkan ide baru dan merencakana proyek; dan 5) sebagai alat berpikir yang mengasyikan karena membantu berpikir 2 kali lebih baik, 2 kali lebih cepat, 2 kali lebih jernih dan lebih menyenangkan.

Menurut Swadarma (2013) Teori yang mendukung penggunaan metode mind mapping dalam proses pembelajaran diantaranya adalah, teori Multiple Intellegence Gardner yang mengemukakan bahwa mind mapping sangat tepat dijadikan sebagai pendekatan pembelajaran sebab dapat memaksimalkan potensi kecerdasan anak sesuai dengan kecerdasannya, terutama anak dengan kecerdasan visual-spesial karena belajar banyak menggunakan warna dan gambar (Swadarma : 2013). Teori berikutnya yaitu teori Skinner bahwa mind mapping adalah metode belajar yang tepat karena semua unsur penguat (reinfoecement) seperti fun, reward, lingkungan yang kondusif dapat diterapkan pada pembelajaran dengan pendekatan mind mapping. Sedangkan teori Gagne menyatakan bahwa mind mapping merupakan salah satu cara yang tepat untuk menyimpan banyak informasi ke dalam memori jangka panjang.

Metode mind mapping dengan pendekatan saintifik merupakan suatu cara yang dilakukan pendidik untuk mempermudah pemahaman konsep peserta didik berkaitan dengan topik yang dipelajari melalui rangkaian kegiatan ilmiah berupa kegiatan mengamati, menanya, mengeksplor, mengasosiasi dan mengkomunikasi. Pendapat ini sejalan dengan pernyataan Buzan (2012) bahwa dengan pembelajaran menggunakan mind mapping, dapat meningkatkan daya ingat peserta didik hingga $78 \%$.

Melalui pembelajaran mind mapping, terjadi keselarasan cara kerja alami otak dalam melakukan berbagai hal, seperti pada daftar informasi panjang yang bisa dialihkan menjadi diagram warna-warni, sangat teratur dan mudah untuk diingat (Buzan : 2013). Berikut adalah langkah-langkah proses pembelajaran matematika peminatan dengan menggunakan metode mind mapping dengan pendekatan saintifik yang dilakukan oleh penulis yang merupakan hasil modifikasi dari pendapat Buzan (2012) dan Ginting (2013), dan penulis memberi nama dengan langkah 8M. Langkah-langkah tersebut adalah: 1) mengamati topik/ permasalahan yang disajikan/ditugaskan, 2) mengidentifikasi permasalahan/ topik yang ditugaskan melalui kegiatan diskusi dan tanya jawab dengan rekan sebaya/sekelompok, 3) membuat bagan dengan terlebih dahulu menuliskan bagian permasalahan pada gambar sentral (utama), 4) menggunakan alur skema, gambar atau foto untuk ide sentral, 5) menggunakan warna, kemudian buatlah garis hubung yang melengkung untuk menghubungkan bagian utama ke cabang-cabang penyelesaian, 6) menggunakan satu kata kunci untuk setiap garis, 7) membuat kesimpulan dari penyelesaian yang dilakukan dan tuliskan di alur bagan/ gambar terakhir, dan 8) mempresentasikan hasil kegiatan mind mapping di depan kelas.

Hasil belajar mempunyai peranan penting dalam proses pembelajaran. Proses penilaian terhadap hasil belajar dapat memberikan informasi kepada pendidik tentang kemajuan peserta didik dalam upaya mencapai tujuan-tujuan belajarnya melalui kegiatan belajar. Anni (2004) menyatakan bahwa, hasil belajar adalah perubahan perilaku yang diperoleh peserta didik setelah melalui beragam aktivitas dalam kegiatan belajar. Sedangkan Dimyati dan Mudjiono 
(2006), yang mengatakan bahwa hasil belajar merupakan proses yang dilalui peserta didik, untuk melihat sejauh mana mereka dapat menguasai pembelajaran setelah mengikuti kegiatan belajar mengajar.

Briggs (1979) berpendapat bahwa hasil belajar adalah seluruh kecakapan dan segala hal yang diperoleh melalui proses belajar mengajar di sekolah yang dinyatakan dengan angka dan diukur dengan menggunakan tes hasil belajar. Tingkat kemajuan dan ketercapaian hasil belajar dari tujuan pembelajaran dapat dilihat melalui proses evaluasi pembelajaran atau tes hasil belajar. Dalam penelitian ini, hasil belajar yang akan ditingkatkan dalam penelitian ini mencakup kompetensi sikap, pengetahuan dan keterampilan. Ketiga kompetensi ini sesuai dengan acuan dalam Permendikbud No 23 tahun 2016 terkait standar penilaian.

\section{METODE PENELITIAN}

Penelitian ini merupakan penelitian deskriptif (descriptive research), yaitu penelitian yang ditujukan untuk menggambarkan fenomena-fenomena yang apa adanya dengan cara menelaah secara teratur dan ketat, mengutamakan objektivitas, dan dilakukan secara cermat, serta tidak ada perlakukan yang dikendalikan bahkan tidak ada pengujian atau uji hipotesis (Furchan, 2004). Penelitian lebih pada menggambarkan hasil belajar berdasarkan metode yang digunakan, dari situasi nyata yang dialami oleh guru sebagai peneliti saat melakukan proses pembelajaran di dalam kelas.

Pelaksanaan penelitian dilakukan mulai tanggal 24 Juli s.d. 29 September 2019 di semester ganjil Tahun Ajaran 2019/2020 pada materi Pertidaksamaan Nilai Mutlak, materi Persamaan dan Pertidaksamaan Rasional, serta pada materi Persamaan dan Pertidaksamaan Irasional untuk kelas X.IPS. Berdasarkan Permendikbud No. 23 Tahun 2016, instrumen penilaian yang dilakukan oleh pendidik selama proses pembelajaran adalah bentuk tes dan non tes, yang dilakukan dalam bentuk tertulis, penugasan, pengamatan kinerja/ tes praktek, proyek, pengamatan selama proses pembelajaran (observasi), penilaian rekan sebaya dan penilaian diri. Pendidik membuat catatan aktivitas yang dilakukan peserta didik selama proses pembelajaran dengan menggunakan buku catatan lapangan (fiel notes) untuk membantu kelancaran pelaksanaan observasi yang dilakukan dan mengantisipasi kekurangan saat melakukan oebservasi, seperti: kurang cermat, kurang berkonsentrasi, tidak berdasarkan perilaku yang ditunjukkan oleh peserta didik sebagai objek yang diamati (Sudjana : 2001).

Pada metode analisis data penelitian, untuk data kuantitatif yang diolah adalah data hasil tes tertulis/ evaluasi akhir, tes unjuk kerja/tes praktek, dan tugas proyek. Tujuan dilakukan testes tersebut untuk mengetahui hasil belajar peserta didik berdasarkan capaian kompetensi pengetahuan dan keterampilan setelah digunakan metode mind mapping dengan pendekatan saintifik dalam proses pembelajaran. Langkah yang dilakukan dalam analisis data, yaitu dengan menghitung nilai capaian rata-rata hasil belajar untuk kompetensi pengetahuan dan keterampilan (tes tertulis dan tes praktek) secara klasikal (per kelas), dan rumus yang digunakan adalah: $=\frac{\text { skor diperoleh }}{\text { skor maksimal }}$.

Pada data kualitatif, data yang dianalisa adalah data hasil observasi, jurnal, penilaian diri dan penilaian rekan sebaya, bertujuan untuk mengetahui pencapaian kompetensi sikap peserta didik sesuai dengan indikator yang telah ditetapkan oleh pendidik. Tidak ada rumus untuk menghitung skor sikap, namun lebih pada hasil analisa terhadap sikap yang ditunjukan peserta didik berdasarkan hasil pengamatan/ observasi yang dilakukan oleh penelitia (guru). Apabila terdapat keterkaitan diantara hasil analisis data kuantitatif dengan data kualitatif, maka akan sangat menunjukkan kesesuaian penggunaan metode mind mapping dengan pendekatan saintifik mencapai keseimbangan pada hasil belajar baik untuk kompetensi sikap, pengetahuan dan keterampilan yang sesuai dengan standar yang telah di tetapkan.

\section{HASIL DAN PEMBAHASAN}

Peningkatan hasil belajar matematika peserta didik berdasarkan kompetensi sikap, pengetahuan dan keterampilan pada materi Pertidaksamaan Nilai Mutlak, materi Persamaan 
dan Pertidaksamaan Rasional, serta materi Persamaan dan Pertidaksamaan Irasional yang proses pembelajarannya menggunakan metode mind mapping dapat dilihat pada tabel berikut.

Tabel 1. Hasil Belajar untuk Kompetensi Sikap, Pengetahuan dan Keterampilan Menggunakan Metode Mind Mapping dengan Pendekatan Saintifik Untuk Kelas X.IPS Tahun Pelajaran 2019/ 2020

\begin{tabular}{|c|c|c|c|c|c|c|}
\hline \multirow{3}{*}{ Materi } & \multicolumn{6}{|c|}{ Nilai Rata-rata Hasil Belajar } \\
\hline & \multicolumn{2}{|c|}{ Sikap } & \multicolumn{2}{|c|}{ Pengetahuan } & \multicolumn{2}{|c|}{ Keterampilan } \\
\hline & $\mathbf{N}$ & $\mathbf{p}$ & $\mathbf{n}$ & $\mathbf{p}$ & $\mathbf{n}$ & $\mathbf{p}$ \\
\hline Persamaan Nila Mutlak & Cukup & $\mathrm{B}$ & 70,00 & $\mathrm{D}$ & 75,00 & $\mathrm{C}$ \\
\hline $\begin{array}{l}\text { Pertidaksamaan Nilai } \\
\text { Mutlak }\end{array}$ & Baik & B & 79,80 & $\mathrm{C}$ & 81,01 & $\mathrm{C}$ \\
\hline $\begin{array}{l}\text { Persamaan dan } \\
\text { Pertidaksamaan } \\
\text { Rasional }\end{array}$ & Baik & B & 80,75 & $\mathrm{C}$ & 82,00 & $\mathrm{C}$ \\
\hline $\begin{array}{l}\text { Persamaan dan } \\
\text { Pertidaksamaan } \\
\text { Irasional }\end{array}$ & Baik & B & 82,05 & $\mathrm{C}$ & 85,75 & $\mathrm{~B}$ \\
\hline
\end{tabular}

Berdasarkan tabel 3.1 di atas, ternyata proses pembelajaran yang menggunakan metode mind mapping dengan pendekatan saintifik dapat meningkatkan hasil belajar matematika peserta didik dengan raihan keseimbangan pada kompetensi sikap, pengetahuan dan keterampilan. Peningkatan hasil belajar peserta didik berdasarkan tabel 3.1 tersebut, terlihat dari selisih presentasi capaian rata-rata hasil belajar sebelum menggunakan metode mind mapping pada materi Persamaan Nilai Mutlak dengan setelah menggunakan metode mind mapping untuk materi Pertidaksamaan Nilai Mutlak yaitu sebesar 9,80\% (kompetensi pengetahuan) dan 6,01\% (kompetensi keterampilan). Sedangkan selisih dari materi Pertidaksamaan Nilai Mutlak ke materi Persamaan dan Pertidaksamaan Rasional sebesar 0,95\% untuk kompetensi pengetahuan dan 0,99\% untuk kompetensi keterampilan. Selisih antara materi Persamaan dan Pertidaksamaan Rasional dan Persamaan dan Pertidaksamaan Irasional, yaitu untuk kompetensi pengetahuan sebesar 1,3\% dan kompetensi keterampilan sebesar $3,75 \%$. Data ini menunjukkan bahwa telah terdapat peningkatan rata-rata hasil belajar matematika peserta didik kelas X.IPS setelah proses pembelajarannya menggunakan metode mind mapping dengan pendekatan saintifik.

Berdasarkan hasil observasi/ pengamatan aktivitas peserta didik dan catatan-catatan kecil (key note) yang dibuat oleh guru, serta hasil analisis instrumen penilaian diri baik dalam bentuk skala sikap maupun pedoman wawancara tertulis, diperoleh temuan bahwa peserta didik merespon positif proses pembelajaran menggunakan metode mind mapping dengan pendekatan saintifik. Respon positif peserta didik ini ditunjukkan oleh presentasi jawaban wawancara tertulis peserta didik sebesar 94,79\% yang menyatakan bahwa saat belajar matematika dan menyelesaikan permasalahannya dengan membuat mind map, menurut peserta didik menjadikan belajar lebih menyenangkan, bersemangat, tidak membosankan, lebih kreatif, dapat berkreasi dan berinovasi, memudahkan memahami konsep yang dipelajari, dapat mengingat materi dengan lebih lama/ tidak mudah lupa dan berbagai komentar positif lainnya yang dikemukakan oleh peserta didik. Hanya ada 5,21\% peserta didik atau 5 orang yang mengemukkan bahwa membuat mind map lebih ribet, apalagi mereka tidak suka menggambar, mereka lebih menyenangi metode lama dan metode ini tidak menjadikan lebih paham dengan konsep yang dipelajari.

Penggunaan metode mind mapping dengan pendekatan saintifik ternyata membuat peserta didik yang tadinya menganggap bahwa belajar matematika menegangkan, sebuah beban, membosankan dan hanya berhubungan dengan deretan angka yang menoton, ternyata mulai dapat membuat peserta didik merasakan kegiatan pembelajaran yang lebih menyenangkan, lebih aktif dan kreatif, termotivasi untuk saling berbagi pengetahuan dan terlibat aktif dalam kegiatan diskusi kelompok. Peserta didik dengan kegiatan berbagi maupun bekerjasama dengan rekan sebaya melalui kreativitas pembuatan mind map menjadi tidak merasa terbebani, walaupun kegiatan yang dilakukan adalah menemukan konsep dan 
menyelesaikan berbagai permasalahan matematika. Pernyataan ini didukung oleh hasil penelitian Karim (2017) bahwa metode mind mapping dapat mengembangkan kreativitas dan menimbulkan perasaan menyenangkan selama proses pembelajaran karena materi yang dipelajari dipahami dengan mengalir begitu saja sesuai alur pemikiran, namun ingatan materi terasa lebih kuat tidak mudah lupa.

Penggunaan metode ini telah menuntut kreativitas dan keaktifan peserta didik selama proses pembelajaran, serta saling membantu maupun bekerjasama bersama rekan kelompoknya, sehingga membuat peserta didik menjadi lebih termotivasi untuk belajar, saling bertoleransi serta bertanggung jawab untuk memberikan hasil yang lebih baik untuk kelompoknya. Hasil pengamatan ini ternyata didukung oleh hasil penelitian Mahmudah (2018) bahwa peserta didik yang menggunakan meodel pembelajaran mind mapping memiliki kemampuan penalaran dan kreativitas yang lebih meningkat berdasarkan acuan pada hasil belajar matematikanya. Mengkondisikan peserta didik dalam aktivitas yang bukan hanya mengembangkan kemampuan otak kiri saat belajar matematika, namun peserta didik pun di tuntut untuk dapat mengembangkan kemampuan otak kanannya saat membuat mind map penyelesaian permasalahan matematika dan menemukan konsep yang dipelajari, ternyata berdampak baik terhadap peningkatan hasil belajar matematika peserta didik baik pada kompetensi sikap, pengetahuan dan keterampilan. Hasil penelitian ini didukung oleh hasil penelitian Yohanie (2015), bahwa hasil belajar dengan model pembelajaran mind mapping lebih baik daripada peserta didik yang mendapatkan pembelajaran langsung.

Kreativitas mengembangkan kemampuan otak kiri maupun otak kanan saat proses menemukan konsep dan menyelesaikan masalah matematika melalui pembuatan mind map, ternyata membuat peserta didik lebih optimal untuk mencapai kesimbangan kompetensi sikap, pengetahuan dan keterampilan. Peserta didik terlihat lebih bersemangat saat belajar matematika karena mereka lebih mudah mamahami materi yang dibahas karena mereka selalu saling berdiskusi dengan keragaman kemampuan kelompoknya, terjadi adanya hubungan timbal balik diantara peserta didik setelah melalui proses pembelajaran ini dan mereka merasa belajar dengan adanya kreativitas pembuatan mind map melalui kegiatan menggambar, mewarnai, membuat alur konsep, menjadi sebuah kegiatan yang menyenangkan dan tidak membosankan.

Berdasarkan data hasil observasi/ pengamatan aktivitas peserta didik dan catatan-catatan kecil (key note) yang dibuat oleh guru dari hasil penelitian ini, menunjukkan bahwa peserta didik telah memiliki respon positif terhadap pembelajaran matematika setelah menggunakan metode mind mapping dengan pendekatan saintifik ini. Hasil penelitian ini sejalan dengan hasil penelitiannya Mawartningsih dan Zuhdiana (2017), bahwa peserta didik sangat merespon positif pembelajaran dengan menggunakan metode mind mapping, yaitu dengan prosentase hasil angket $97,06 \%$ peserta didik yang merespon positif.

Selain itu, data hasil observasi yang diperoleh dalam penelitian ini didukung pula oleh data hasil angket skala sikap. Sebanyak 93,75\% peserta didik menyatakan bahwa mereka tidak setuju apabila belajar matematika pendidik hanya menjelaskan materi saja, mereka merasa bosan apabila hanya mendengar pendidik menjelaskan, dan kesulitan memahami konsep yang dipelajari apabila hanya berupa penjelasan materi. Sebanyak 95,83\% peserta didik menjadi lebih memahami materi matematika yang dipelajari dengan cara menggambar mind map, tidak merasa kesulitan membuat mind map saat menyelesaikan permasalahan matematika dan tertarik belajar matematika dengan menggambar mind map untuk menyelesaikan permasalahan matematika.

Berikut ini adalah pernyataan-pernyataan yang dikemukakan oleh peserta didik dalam lembar angket terkait dengan metode pembelajaran mind mapping dengan pendekatan saintifik, dan contoh mind mapping karya peserta didik: 


\section{Gambar 1. Penyataan Peserta Didik Terkait Metode Mind Mapping}

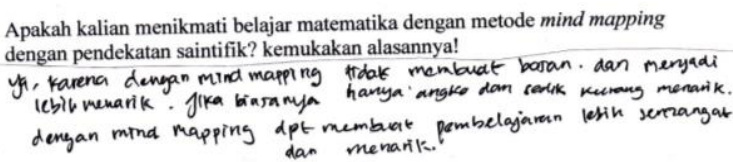

Apakah kalian menjadi lebih paham dengan materi yang dibahas setelah membuat gambar mind map/peta konsep? kemukakan alasannva!

Pasti dong, lebih menterti soya, rarena dongan mem buat gambar peta lonsep lata akonmengerti apo Jajo yang arar clikelajatio

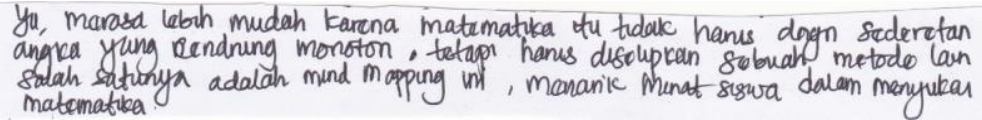

Gambar 2. dan Contoh Hasil Karya Mind Mapping Peserta Didik

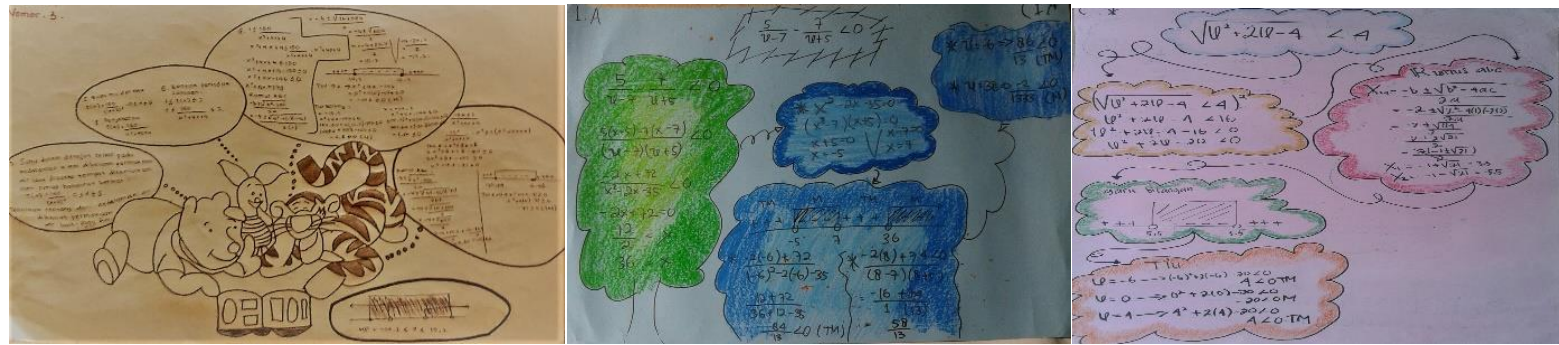

\section{KESIMPULAN}

Secara umum dapat disimpulkan bahwa hasil belajar matematika peserta didik pada capaian kompetensi sikap, pengetahuan dan keterampilan di kelas X.IPS saat membahas materi Pertidaksaman Nilai Mutlak, materi Persamaan dan Pertidaksaman Rasional, dan materi Persamaan dan Pertidaksaman Irasional, ternyata rata-rata telah memperoleh nilai sesuai dengan standar yang telah ditetapkan (melampaui batasan nilai ketuntasan). Presentase capaian nilai rata-rata hasil belajar matematika pada materi Pertidaksaman Nilai Mutlak untuk kompetensi sikap adalah baik, pengetahuan $79,80 \%$ dan keterampilan $81,01 \%$. Sedangkan materi Persamaan dan Pertidaksaman Rasional untuk kompetensi sikap adalah baik, pengetahuan $80,75 \%$ dan keterampilan $82,0 \%$. Pada materi Persamaan dan Pertidaksaman Irasional untuk kompetensi sikap adalah baik, pengetahuan $82,05 \%$ dan keterampilan $82,75 \%$. Walaupun predikat untuk kompetensi pengetahuan maupun keterampilan masih ada dalam ranah cukup (C), namun nilai rata-rata masih melebihi nilai KKM (> 73). Nilai capaian ratarata yang diraih peserta didik tersebut menunjukan bahwa terdapat peningkatan hasil belajar matematika peserta didik kelas X.IPS melalui penggunaan metode mind mapping dengan pendekatan saintifik untuk materi Pertidaksamaan Nilai Mutlak, Persamaan dan Pertidaksamaan Rasional-Irasional.

Metode pembelajaran mind mapping dengan pendekatan saintifik, bukan hanya digunakan untuk membahas materi matematika, namun metode ini dapat pula di cobakan untuk diuji cobakan pada mata pelajaran lain, sehingga disarankan untuk dilakukan penelitian lanjutan untuk mata pelajaran lain. Penting peran seorang guru untuk selalu berusaha memahami akan kesulitan belajar yang dialami peserta didiknya. Hal ini berguna untuk pemberian bantuan dengan menemukan alternatif bentuk yang tepat sesuai dengan letak dan karakteristik kesulitan yang dialami peserta didik maupun materi yang akan dipelajari. Peningkatan hasil belajar berdasarkan kesimbangan capaian kompetensi sikap, pengetahuan dan keterampilan yang diperoleh peserta didik dengan menggunakan metode mind mapping dengan pendekatan saintifik, hanya merupakan salah satu metode pembelajaran yang dapat digunakan dalam proses 
pembelajaran, oleh karena itu perlu dikembangkan metode-metode lainnya sesuai dengan karakteristik peserta didik dan materi yang akan dibahas.

\section{DAFTAR PUSTAKA}

Anni, Catharina, T. (2004). Psikologi Belajar. Semarang: IKIP Semarang Press.

Buzan, Tony. (2012). Buku pintar Mind Map. Jakarta: Gramedia Pustaka.

Dimyati dan Mudjiono. (2006). Belajar dan Pembelajaran (Cetakan 3). Jakarta: Rineka Cipta.

Ekawati, Aminah. (2014). Pengaruh Motivasi dan Minat Terhadap Hasil Belajar Matematika Kelas VII di SMPN 13 Banjarmasin. LENTERA, Jurnal Ilmiah Kependidikan. Vol.9, no. 2 (2014), hal. $1-10$.

Furchan, A. (2004). Pengantar Penelitian dalam Pendidikan. Yogyakarta: Pustaka Pelajar Offset.

Ginting, Monto, K. Br. (2013). Artikel Ilmiah: Efektivitas Model Mind Map dalam Meningkatkan Kemampuan dalam Menulis Artikel oleh Siswa Kelas XI SMA Swasta Rakyat Sei Gelugur Tahun Pembelajaran 2012/2013. Medan: Universitas Negeri Medan. http://idealmathedu.p4tkmatematika.org ISSN 2407-8530.

Karim, Abdul. (2017). Efektivitas Penggunaan Metode Mind Map pada Pelatihan Pengembangan Penguasaan Materi Pembelajaran. Journal of Social Science Teaching, Jurnal IJTIMAIYA_Vol. 1 No. 1 Juli-Desember 2017.

Mahmudah, F.H. (2018). Penerapan Model Pembelajaran Mind Mapping Untuk Meningkatkan Penalaran Dan Kreativitas Peserta Didik. Indonesian Digital Journal of Mathematics and Education Volume 5 Nomor 9 Tahun 2018.

Mawartningsih, L. dan Zuhdiana, A.A. (2017). Penerapan Model Pembelajaran Mind Mapping dengan Media Kartu untuk Meningkatkan Hasil Belajar Siswa. Proceeding Biology Education Conference Volume 14, Nomor 1 Halaman 604-610. Oktober 2017. p-ISSN: 2528-5742.

Mulyana, Deddy. (2008). Ilmu Komunikasi: Suatu Pengantar. Bandung: Remaja Rosdakarya

Olivia, Femi. (2008). Gembira Belajar dengan Mind Mapping: Bantu Anak Menguasai "senjata rahasia" para Jenius untuk Melejit Prestasi di Sekolah. Jakarta: Elex Media Komputindo.

Shoimin, Aris. (2014). 68 Model Pembelajaran Inovatif dalam Kurikulum 2013. Yogyakarta: Ar-Ruzz Media.

Sudjana. (2001). Metode Statistik. Bandung: Tarsito.

Swadarma, Doni. (2013). Mind Mapping dalam Kurikulum Pembelajaran. Jakarta: Alex Media Komputindo.

Yohanie, Dian Devita. (2015). Eksperimentasi Pembelajaran Matematika dengan Model Mind Mapping terhadap Hasil Belajar Siswa ditinjau dari Motivasi Belajar Sisw Kelas X SMA Negeri 8 Kediri. Jurnal Math Educator Nusantara, Vol1. No.1. Diakses tanggal 14 April 2017. (http://ojs.unpkediri.ac.id/index.php/matematika/article/view/123). 